\title{
Evaluation of salt content and effectiveness of excessive salt reduction methods in selected commercially available dried fish types in Sri Lanka
}

\author{
D. P. Lakmini ${ }^{1}$, Helani Munasinghe ${ }^{2}$, A. Buddhika G. Silva* ${ }^{3}$, P.G.S.M. De Silva ${ }^{4}$, Renuka \\ Jayatissa $^{3}$
}

\author{
${ }^{I}$ Department of Chemistry, Faculty of Applied Sciences, University of Sri Jayewardenepura, \\ Gangodawila, Nugegoda, Sri Lanka. \\ ${ }^{2}$ Department of Botany, Faculty of Applied Sciences and Centre for Plant Materials and Herbal \\ Products Research, University of Sri Jayewardenepura, Gangodawila, Nugegoda, Sri Lanka. \\ ${ }^{3}$ Department of Nutrition, Medical Research Institute, Colombo 08, Sri Lanka. \\ ${ }^{4}$ Department of Electron Microscopy, Medical Research Institute, Colombo 08, Sri Lanka.
}

Date Received: 08-10-2021 Date Accepted: 17-12-2021

\begin{abstract}
High salt intake elevates the risk of non-communicable diseases such as high blood pressure, cardiovascular diseases and stroke worldwide. Sri Lanka has recorded in 2010 as the country with highest average fish \& fish products consumption in South Asia. In the current study, salt in ten types of commonly available dried fish namely; sprats, prawns, smoothbelly sardinella, queen fish, cat fish, sail fish, shark, skipjack tuna, Bombay duck and trenched sardinella was analyzed and determined salt reduction methods with minimal protein loss. Four salt reduction methods were tested; Method 1: washed with water at Room Temperature (RT) for five times; Method 2: washed with water for five times at RT and kept in hot water for 5min; Method 3: washed with water for five times at RT and boiled for $5 \mathrm{~min}$; Method 4: washed with water for five times at RT and kept in coconut water for 5min. Using Volhard method, sodium chloride was analyzed while protein was determined using Kjeldahl method. All four methods showed significant reduction of salt level in tested dried fish $(\mathrm{p}<0.05)$. Among the tested salt reduction methods, Method 3 showed the highest salt reduction for all types of dried fish except smoothbelly sardinella and cat fish.The highest salt mean value of $28.8 \%$ was recorded in queen fish and the lowest mean value of $12.8 \%$ was recorded in smoothbelly sardinella. The highest protein loss was recorded in Method 3. To reduce considerable amount of salt, the easiest and fairly effective method is method 1 except for prawns and Shark. Although higher salt reduction showed in method 2 and 3, they are not recommended due to high protein loss, high energy expenditure and reduction of freshness of dried fish. Method 4 can be applied for all dried fish types because it is economical and reduces considerable amount of salt, removes less amount of protein comparatively. The results revealed that all tested dried fish except smoothbelly sardinella contain significantly high amount of salt $(\mathrm{p}<0.05)$ than the standard value specified $(12 \%)$ by the Sri Lanka Standards Institution (SLSI).
\end{abstract}

Keywords: Dried fish, protein loss, salt-intake, salt reduction, non-communicable diseases

*Correspondence: buddhika-gayani@mri.gov.lk

Tel: +94712088220

(C) University of Sri Jayewardenepura 


\section{Introduction}

Dried fish is a popular as well as a common food component found in the Sri Lankan traditional meal which is considered as one of the major sources of animal protein. Around $80 \%$ protein can be found as the major constituent in 100g of dried fish and it is higher than the animal meat (Siddhnath et al., 2020). In Sri Lanka, fish and fishery products fulfill 55\% of the animal protein intake of people (Reksten et al., 2020). Sri Lanka has recorded the highest average national 'fish \& fish products consumption' of 15.3 $\mathrm{kg}$ /capita/year (2010) in South Asia, based on the household consumption survey conducted by the Food and Agriculture Organization of the United Nation (FAO), Regional Office for Asia and the Pacific while 'marine \& freshwater dried fish consumption' is $3.8 \mathrm{~kg}$ /capita/year (Needham \& Funge-Smith, 2015). Hence, as a developing country, consumption of dried fish in Sri Lanka is at a high level.

Most of the time, fish rapidly deteriorates due to microbial actions at room temperature and lose their quality. Salting, smoking and drying are commonly used traditional methods to preserve fish for a longer time (Yam, Khomeiri, Amirkhani, \& Sabagh, 2015). Using these traditional methods, fish is preserved by reducing the moisture content. Usually, high amount of salt is added to fish in drying method, in order to increase shelf life, to enhance the flavor and to reduce microbial growth. Salt performs preservation task by reducing water activity to a certain extend which is required by various microorganisms to grow. Moisture amount present in dried fish influences the quality of food. Not only the moisture amount but insect infestation, mite attacks, mould attacks, storage conditions, environmental factors and other concerns also affect for the quality of the dried fish and they may lead to the post-harvest loss (Mansur, Rahman, Khan, Reza, \& Uga, 2013). Consumer preference of buying dried fish depends on appearance, flavor, odor, texture and quality. Since moisture content affects all of these parameters, it plays a major role in customer demand as well in determining commercial value of dried fish. If moisture content is high, it adversely affects the physical properties of dried fish. High moisture content enhances the microbial growth especially fungal growth on dried fish and results in reduced quality.

Excessive consumption of salt leads to Non-Communicable Diseases (NCDs) such as hypertension, high blood pressure, cardiovascular diseases and stroke worldwide (Ha, 2014). Daily recommended dietary salt intake is less than $5 \mathrm{~g}$ per day according to the World Health Organization (WHO), 2012 and the FAO. According to the WHO recommendations, salt intake of less or equal to $5 \mathrm{~g}$ per day for adults reduces cardiovascular disease and hypertension by reducing blood pressure (BP) (WHO, 2012).

In Sri Lanka, regulation under food act is not yet prepared to monitor the salt content of dried fish samples. Standard issued by Sri Lanka Standard Institute mentioned that the salt content of dried fish sample cannot exceed $12 \%$ as $\mathrm{NaCl}$ by mass on dry basis (SLS,2007).

Therefore, the present study was conducted to determine salt content of commonly available ten types of dried fish in Colombo Municipal Council (CMC) region. Furthermore, salt reduction methods which can be applied in households were tested for dried fish. Effectiveness of each salt reduction method was determined based on amount of reduced salt content by each method and minimal protein loss after applying each salt reduction method. Moisture content in each type of dried fish was also determined.

\section{Materials and methods}

A total of 60 samples of dried fish collected from Colombo Municipal Council (CMC) region were tested for salt content, salt reduction methods, moisture content and protein content. Six samples from each type of selected commonly available dried fish in the local market namely; Stolephorus sp. (Sprats), Penaeus sp.(Prawns), Amblygaster leiogaster (Smoothbelly sardinella), Seriphus politus (Queen fish), Siluriformes (Cat fish), Istiophorus platypterus (Sail fish), Carcharhinus sp. (Shark), Katsuwonus pelamis 
(Skipjack tuna), Harpadon nehereus (Bombay duck) and Amblygaster sirm (Trenched sardinella) were analyzed for above parameters. Samples were collected randomly within CMC region which were sold during August - November, 2018.

\subsection{Determination of moisture content}

Moisture content was determined using the oven drying AOAC method (AOAC, 2005).

\subsection{Determination of salt content}

Salt (chlorine as sodium chloride) in dried fish was determined using AOAC Volhard volumetric method (AOAC, 2005).

\subsection{Methods to reduce excessive salt}

Four methods of salt reduction which can be applied in households were tested. These methods were;

I. $\quad$ Method 1: washing with water for 5 times at Room Temperature (RT)

II. Method 2: Method 1 + kept in hot water for 5 min

III. Method 3: Method 1+boiled for 5 min

IV. Method 4: Method $1+$ kept in coconut water for 5 min

(I) Method 1 - A weight of $10.0 \mathrm{~g}$ of each dried fish type was put into beakers separately and washed with $25 \mathrm{~mL}$ of distilled water for 5 times.

(II) Method 2 - A weight of $10.0 \mathrm{~g}$ of each dried fish type was put into beakers separately and washed with $25 \mathrm{~mL}$ of distilled water for 5 times. Then $25 \mathrm{~mL}$ of hot distilled water was added to each beaker, and kept for $5 \mathrm{~min}$.

(III) Method 3 - A weight of $10.0 \mathrm{~g}$ of each dried fish type was put into beakers separately and washed with $25 \mathrm{~mL}$ of distilled water for 5 times. Then $25 \mathrm{~mL}$ of distilled water was added to each beaker, boiled for 5 min using a hot plate.

(IV) Method 4 - A weight of $10.0 \mathrm{~g}$ of each dried fish type was put into beakers separately and washed with $25 \mathrm{~mL}$ of distilled water for 5 times. Then $25 \mathrm{~mL}$ of fresh coconut water was added to each beaker and kept for $5 \mathrm{~min}$.

After applying each salt reduction method, all samples were dried at $105^{\circ} \mathrm{C}$ until constant weight was obtained to remove moisture. Then they were tested for the salt content.

\subsection{Determination of protein content}

Nitrogen content of dried fish samples before and after applying salt reduction methods were determined in triplicate by modified Kjeldahl method ( AMC, 1979). N\% was converted to protein content by multiplying of $\mathrm{N} \%$ by 6.25 .

*Correspondence: buddhika-gayani@mri.gov.lk

Tel: +94 712088220

(C) University of Sri Jayewardenepura 


\section{Results and Discussion}

\subsection{Salt content}

Mean salt amount of tested 10 types of raw dried fish in CMC area is shown in Table 1. According to the Table 1, the highest mean salt content of $28.8 \%$ was recorded in Queen fish and the lowest mean salt content of $12.83 \%$ was recorded in Smoothbelly sardinella.

Table 1: Average salt amount in grams per $100 \mathrm{~g}$ of dried fish.

\begin{tabular}{|c|c|c|c|c|}
\hline \multirow{2}{*}{$\begin{array}{l}\text { No of } \\
\text { samples }\end{array}$} & \multicolumn{3}{|c|}{ Type of dried fish } & \multirow{2}{*}{$\begin{array}{l}\text { Mean } \pm \text { SD } \\
\text { content of salt } \\
\text { (on dry basis) }\end{array}$} \\
\hline & Scientific name & Sinhala name & Common name & \\
\hline 6 & Stolephorus sp. & Halmessa & Sprats & $23.23 \pm 3.46$ \\
\hline 6 & Penaeus sp. & Issa & Prawns & $27.91 \pm 1.27$ \\
\hline 6 & $\begin{array}{l}\text { Amblygaster } \\
\text { leiogaster }\end{array}$ & Keeramin & Smoothbelly sardinella & $12.83 \pm 2.73$ \\
\hline 6 & Seriphus politus & Katta & Queen fish & $28.80 \pm 3.84$ \\
\hline 6 & Siluriformes & Angulu & Cat fish & $18.13 \pm 2.60$ \\
\hline 6 & $\begin{array}{l}\text { Istiophorus } \\
\text { platypterus }\end{array}$ & Thalapath & Sail fish & $24.32 \pm 3.24$ \\
\hline 6 & Carcharhinus sp. & Mora & Shark & $18.40 \pm 0.49$ \\
\hline 6 & Katsuwonus pelamis & Bala & Skipjack tuna & $16.45 \pm 0.44$ \\
\hline 6 & Harpadon nehereus & Bombili & Bombay duck & $19.62 \pm 0.10$ \\
\hline 6 & Amblygaster sirm & Hurullo & Trenched sardinella & $19.54 \pm 0.14$ \\
\hline
\end{tabular}

As Figure 1 shows, except Smoothbelly sardinella, all the other tested types of dried fish available in $\mathrm{CMC}$ area were found to contain significantly higher amount of salt than the standard value ( $p$ value $<0.05)$. Figure 1 clearly shows that all the sample have higher salt content than the existing Sri Lankan standard value (SLS, 2007).

Similar research conducted in Sri Lanka has highlighted that commercially available dried fish in local market is not suitable for human consumption due to high amount of salt and this study also reveals that dried fish in local market exceeds the standard accepted salt content of $12 \%$ on dry basis (Nuwanthi, Madage, Hewajulige, \& Wijesekera, 2016).

"The processing of dried salted fish" published by the Fisheries Research Board of Canada has stated that if salt concentration is greater than $12 \%$ by weight of the green fish, the bacteria spoiling fresh fish cannot survive very long except halophiles (Beatty \& Fougere, 1957). 


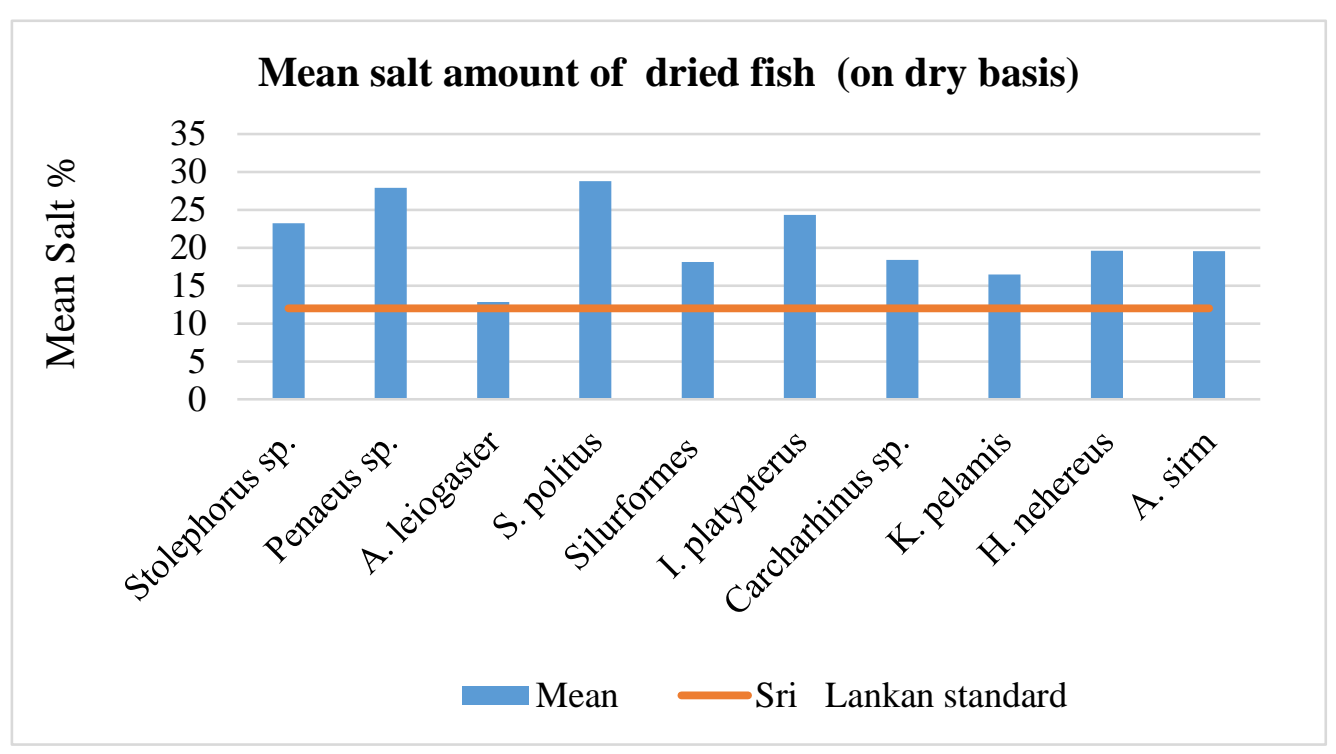

Figure 1. Mean salt percentage of each dried fish samples.

Commercialized salted-dried cod with more than $16 \%$ salt content, have a higher shelf life due to the lower water activity and only halophilic microbes are able to grow in these dried cod products as reported in (Brás \& Costa, 2010). Wide variety of fungi may be a reason for spoiled dried fish and they are capable of deteriorating the quality of dried fish. (Atapattu \& Samarajeewa, 1990) has shown that isolated fungi from dried fish had zero growth in synthetic media having more than $30 \% \mathrm{NaCl}$. This study suggests that 20-30\% salt concentrations are effective for controlling fungal growth on dried fish. The excess salt addition would be a result of these facts and suggest the necessity of salt reduction methods in cooking dried fish.

A study done in Jaffna district, Sri Lanka on biochemical qualities of dried fish (Talang queen dried fish) has recorded the percentage of sodium chloride between $35.02 \%$ and $28.68 \%$ while $17.52 \%$ in experimentally prepared samples. This study showed that sodium chloride content of all five samples was greater than the Sri Lankan Standard. Further it says, the amount of salt added during the preparation of dried fish is the reason for the variation in the sodium chloride content among samples (Sivashanthini. K., 2012). Another study conducted in Sri Lanka has shown that $91 \%$ of the imported dried fish samples and $54 \%$ of locally manufactured dried fish samples contained salt content above $12 \%$. Further it showed, local samples had less amount of salt compared to imported samples (Ginigaddarage et al., 2018).

Mean salt percentages in each type of dried fish after applying above salt reduction methods are shown in Table 2. As shown in Table 2, after applying each salt reduction method, salt amount has decreased significantly $(\mathrm{p}<0.05)$, compared to the salt amount in raw dried fish.

According to Figure 2, the highest salt reduction method of dried fish is method 3, with percentage reduction ranges from $85.58 \%-99.70 \%$. When boiling, usually high salt reduction percentage is observed because solubility of salt increases with increasing temperature. Method 2 also shows very similar results to method 3. Both methods decrease high amount of salt due to increased temperature of water. All four methods reduce significant amount of salt content in tested dried fish types than the raw dried fish (p < 0.05). Compared to method 1, method 4 reduces salt content below 12\% limit in all dried fish types (SLS, 2007). When applying method 2 and 3, extra energy has to be used and the freshness of dried fish is lost

*Correspondence: buddhika-gayani@mri.gov.lk

Tel: +94712088220

(C) University of Sri Jayewardenepura 
before cooking. But use of coconut water is more economical and considerable amount of salt can be reduced before cooking while maintaining freshness.

Table 2: Mean salt percentage in each type of dried fish after applying salt reduction methods. Results are given as mean \pm SD of six samples. Different superscripts in the same row indicate significant differences $(\mathrm{P}<0.05)$.

\begin{tabular}{|c|c|c|c|c|c|}
\hline \multirow[t]{2}{*}{ Dried fish } & \multicolumn{5}{|c|}{ Method } \\
\hline & Raw & $\begin{array}{l}\text { M1 } \\
\text { (washed) }\end{array}$ & $\begin{array}{l}\text { (M2) } \\
\text { washed_- } \\
\text { hot water }\end{array}$ & $\begin{array}{l}\text { (M3) } \\
\text { washed_- } \\
\text { boiled }\end{array}$ & $\begin{array}{l}\text { (M4) } \\
\text { washed_- } \\
\text { coconut water }\end{array}$ \\
\hline Stolephorus sp. & $23.23 \pm 3.46^{\mathrm{a}}$ & $6.67 \pm 0.05^{b}$ & $4.53 \pm 0.41^{b, c}$ & $0.07 \pm 0.07^{\mathrm{d}}$ & $2.20 \pm 0.14^{\mathrm{c}, \mathrm{d}}$ \\
\hline Penaeus sp. & $27.91 \pm 1.27^{\mathrm{a}}$ & $24.35 \pm 1.74^{b}$ & $6.52 \pm 0.17^{\mathrm{c}}$ & $4.00 \pm 0.18^{\mathrm{d}}$ & $10.18 \pm 0.20^{\mathrm{c}}$ \\
\hline Amblygaster leiogaster & $12.83 \pm 2.73^{\mathrm{a}}$ & $6.83 \pm 0.11^{b}$ & $2.79 \pm 0.02^{c}$ & $1.85 \pm 0.01^{\mathrm{c}}$ & $1.83 \pm 0.02^{\mathrm{c}}$ \\
\hline Seriphus politus & $28.80 \pm 3.84^{\mathrm{a}}$ & $9.91 \pm 0.03^{b}$ & $1.91 \pm 0.02^{\mathrm{c}}$ & $1.85 \pm 0.04^{\mathrm{c}}$ & $9.87 \pm 0.08^{b}$ \\
\hline Siluriformes & $18.13 \pm 3.24^{\mathrm{a}}$ & $9.78 \pm 0.13^{b}$ & $1.86 \pm 0.02^{\mathrm{c}}$ & $1.82 \pm 0.02^{\mathrm{c}}$ & $1.77 \pm 0.02^{\mathrm{c}}$ \\
\hline Istiophorus platypterus & $24.32 \pm 2.60^{\mathrm{a}}$ & $9.78 \pm 0.15^{b}$ & $1.85 \pm 0.01^{\mathrm{c}}$ & $1.83 \pm 0.01^{\mathrm{c}}$ & $9.55 \pm 0.33^{b}$ \\
\hline Carcharhinus sp. & $18.40 \pm 0.49^{\mathrm{a}}$ & $16.35 \pm 2.11^{b}$ & $5.77 \pm 0.06^{\mathrm{c}}$ & $1.78 \pm 0.01^{\mathrm{d}}$ & $5.73 \pm 0.11^{c}$ \\
\hline Katsuwonus pelamis & $16.45 \pm 0.44^{\mathrm{a}}$ & $9.77 \pm 0.14^{b}$ & $1.77 \pm 0.03^{c}$ & $1.77 \pm 0.02^{\mathrm{c}}$ & $1.77 \pm 0.02^{\mathrm{c}}$ \\
\hline Harpadon nehereus & $19.62 \pm 0.10^{\mathrm{a}}$ & $3.53 \pm 0.05^{\mathrm{c}}$ & $1.77 \pm 0.01^{\mathrm{d}}$ & $1.77 \pm 0.02^{\mathrm{d}}$ & $8.20 \pm 0.06^{b}$ \\
\hline Amblygaster sirm & $19.54 \pm 0.14^{\mathrm{a}}$ & $9.24 \pm 0.11^{\mathrm{b}}$ & $3.44 \pm 0.04^{c}$ & $2.37 \pm 0.02^{\mathrm{d}}$ & $3.43 \pm 0.09^{c}$ \\
\hline
\end{tabular}




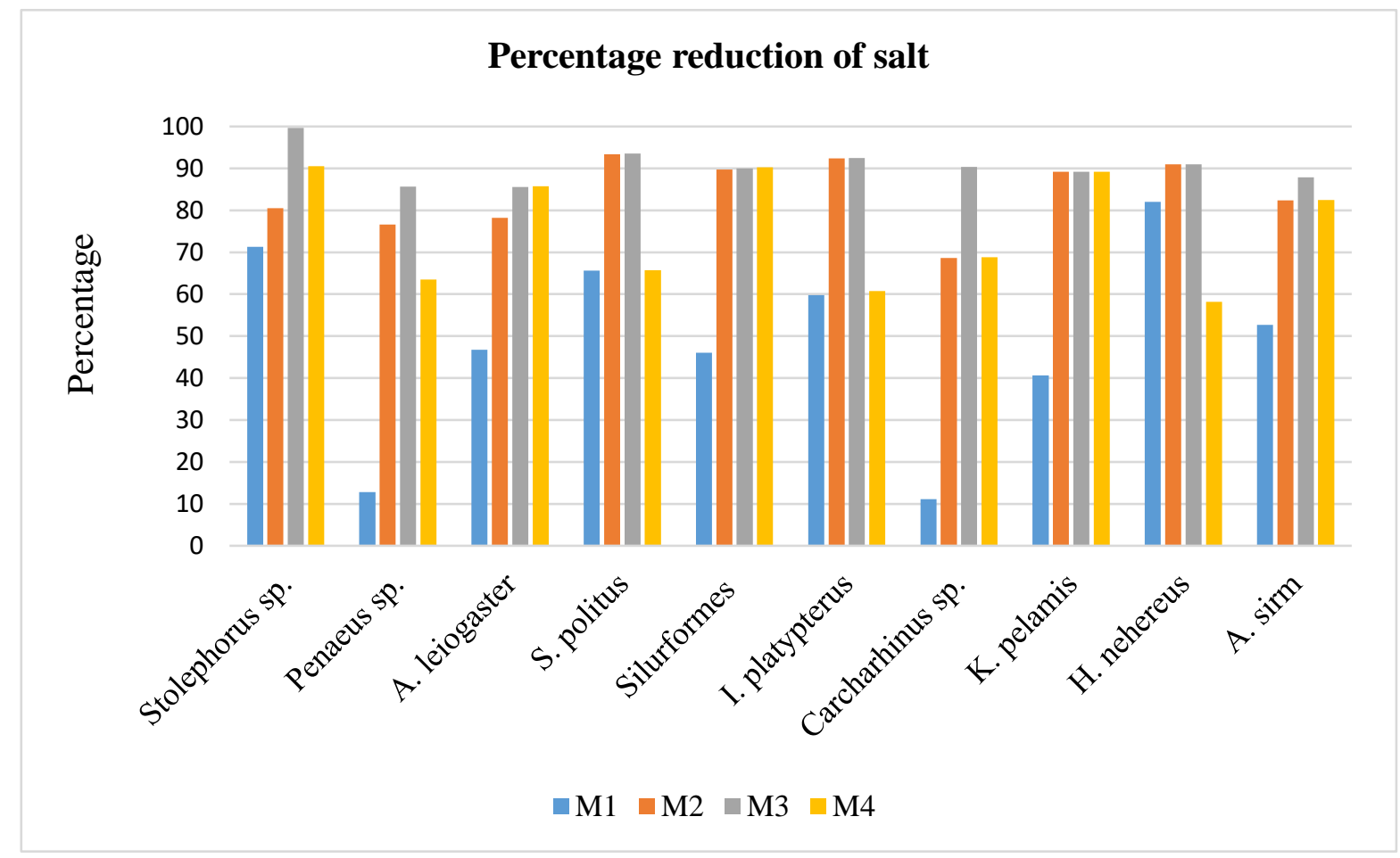

Figure 2. Percentage reduction of salt in each type of dried fish.

\subsection{Protein content}

Table 3 shows the protein content of raw dried fish and remained protein content in dried fish after applying salt reducing methods. The highest protein content of $76.17 \%$ was recorded in dried sprats and the lowest protein content of $58.96 \%$ was recorded in dried prawns.

*Correspondence: buddhika-gayani@mri.gov.lk

Tel: +94712088220

(C) University of Sri Jayewardenepura 
Table 3: Protein percentage remained in dried fish (dry basis) after applying each method. [Results are given as mean \pm S.D. of six samples. Different superscripts in the same row indicate significant differences $(\mathrm{P}<0.05)]$

\begin{tabular}{|c|c|c|c|c|c|}
\hline \multirow[t]{2}{*}{ Dried fish } & \multicolumn{5}{|c|}{ Method } \\
\hline & Raw & M1 & $(\mathrm{M} 2)$ & (M3) & (M4) \\
\hline & & (washed) & $\begin{array}{l}\text { washed_- } \\
\text { hot water }\end{array}$ & $\begin{array}{l}\text { washed__ } \\
\text { boiled }\end{array}$ & $\begin{array}{l}\text { washed_- } \\
\text { coconut water }\end{array}$ \\
\hline Stolephorus sp. & $76.17 \pm 1.00^{\mathrm{a}}$ & $63.75 \pm 0.04^{b}$ & $59.95 \pm 0.04^{\mathrm{c}, \mathrm{d}}$ & $58.36 \pm 1.00^{\mathrm{d}}$ & $60.96 \pm 1.00^{c}$ \\
\hline Penaeus sp. & $58.96 \pm 0.01^{\mathrm{a}}$ & $54.10 \pm 0.20^{b}$ & $51.76 \pm 0.02^{\mathrm{b}, \mathrm{c}}$ & $51.10 \pm 0.20^{c}$ & $53.05 \pm 2.00^{\mathrm{b}, \mathrm{c}}$ \\
\hline $\begin{array}{l}\text { Amblygaster } \\
\text { leiogaster }\end{array}$ & $73.77 \pm 0.20^{\mathrm{a}}$ & $61.61 \pm 0.02^{b}$ & $59.52 \pm 1.00^{\mathrm{b}, \mathrm{c}}$ & $56.59 \pm 3.00^{c}$ & $60.79 \pm 0.20^{\mathrm{b}}$ \\
\hline $\begin{array}{l}\text { Seriphus } \\
\text { politus }\end{array}$ & $62.35 \pm 1.00^{\mathrm{a}}$ & $60.48 \pm 0.07^{b}$ & $58.71 \pm 0.01^{\mathrm{c}}$ & $56.49 \pm 0.02^{d}$ & $58.99 \pm 1.00^{\mathrm{b}, \mathrm{c}}$ \\
\hline Silurformes & $63.94 \pm 0.01^{\mathrm{a}}$ & $60.40 \pm 0.10^{b}$ & $54.46 \pm 1.00^{c}$ & $54.34 \pm 0.01^{\mathrm{c}}$ & $59.77 \pm 0.02^{\mathrm{b}}$ \\
\hline $\begin{array}{l}\text { Istiophorus } \\
\text { platypterus }\end{array}$ & $66.63 \pm 0.00^{\mathrm{a}}$ & $63.26 \pm 0.20^{\mathrm{b}}$ & $60.95 \pm 0.03^{b}$ & $58.45 \pm 0.30^{c}$ & $62.47 \pm 2.00^{\mathrm{b}}$ \\
\hline $\begin{array}{l}\text { Carcharhinus } \\
\text { sp. }\end{array}$ & $70.27 \pm 2.00^{\mathrm{a}}$ & $62.42 \pm 0.02^{\mathrm{b}}$ & $60.74 \pm 2.00^{\mathrm{b}}$ & $58.72 \pm 2.00^{\mathrm{b}}$ & $61.61 \pm 1.00^{\mathrm{b}}$ \\
\hline $\begin{array}{l}\text { Katsuwonus } \\
\text { pelamis }\end{array}$ & $69.31 \pm 0.01^{\mathrm{a}}$ & $64.33 \pm 1.00^{\mathrm{b}}$ & $60.99 \pm 0.01^{\mathrm{c}}$ & $59.92 \pm 0.02^{c}$ & $61.33 \pm 1.00^{c}$ \\
\hline $\begin{array}{l}\text { Harpadon } \\
\text { nehereus }\end{array}$ & $74.56 \pm 1.00^{\mathrm{a}}$ & $57.86 \pm 4.00^{\mathrm{b}}$ & $54.88 \pm 2.00^{\mathrm{b}}$ & $54.63 \pm 3.00^{\mathrm{b}}$ & $56.62 \pm 0.20^{b}$ \\
\hline $\begin{array}{l}\text { Amblygaster } \\
\text { sirm }\end{array}$ & $64.75 \pm 0.01^{\mathrm{a}}$ & $55.33 \pm 0.01^{\mathrm{c}}$ & $52.66 \pm 0.03^{d}$ & $51.24 \pm 0.10^{\mathrm{e}}$ & $60.96 \pm 1.00^{b}$ \\
\hline
\end{tabular}

A similar study indicates that the crude protein contents of tested three dried krill varieties (crustaceans) are $71.6 \%, 57.4 \%$, and 54.6\% dry weight for Sri Lankan, Indonesian, and Indian varieties respectively (Abeywickrama \& Attygalle, 2014). (Ullah, Hazarika, \& Handique, 2016) has found that the protein content of ten types of dried fish in India ranged from $28.63 \%$ to $53.84 \%$.

According to the results, protein loss has occurred in each salt reduction method. As published by Brás \& Costa, 2010, compositional variations are taken placed by gaining salt, loosing water and other soluble components together with proteins, during the salting process of cod. Brás \& Costa, 2010 pointed out that this compositional change leads to a totally different taste and a texture of cooked cod. Further this study says that, at high salt concentrations, proteins present in fish muscles denature causing shrinkage and leads to loss of water.

The highest percentage of protein retention was reported from method 1 and the highest percentage of protein loss occurred from method 3. 
According to Table 3, there is no significant difference in remaining percentage of protein after applying M1 and M4 (p>0.05) except two types of dried fish; Stolephorus sp. (Sprats) and Katsuwonus pelamis (Skipjack tuna).

Figure 3 shows that the percentage reduction of protein in each dried fish sample graphically.

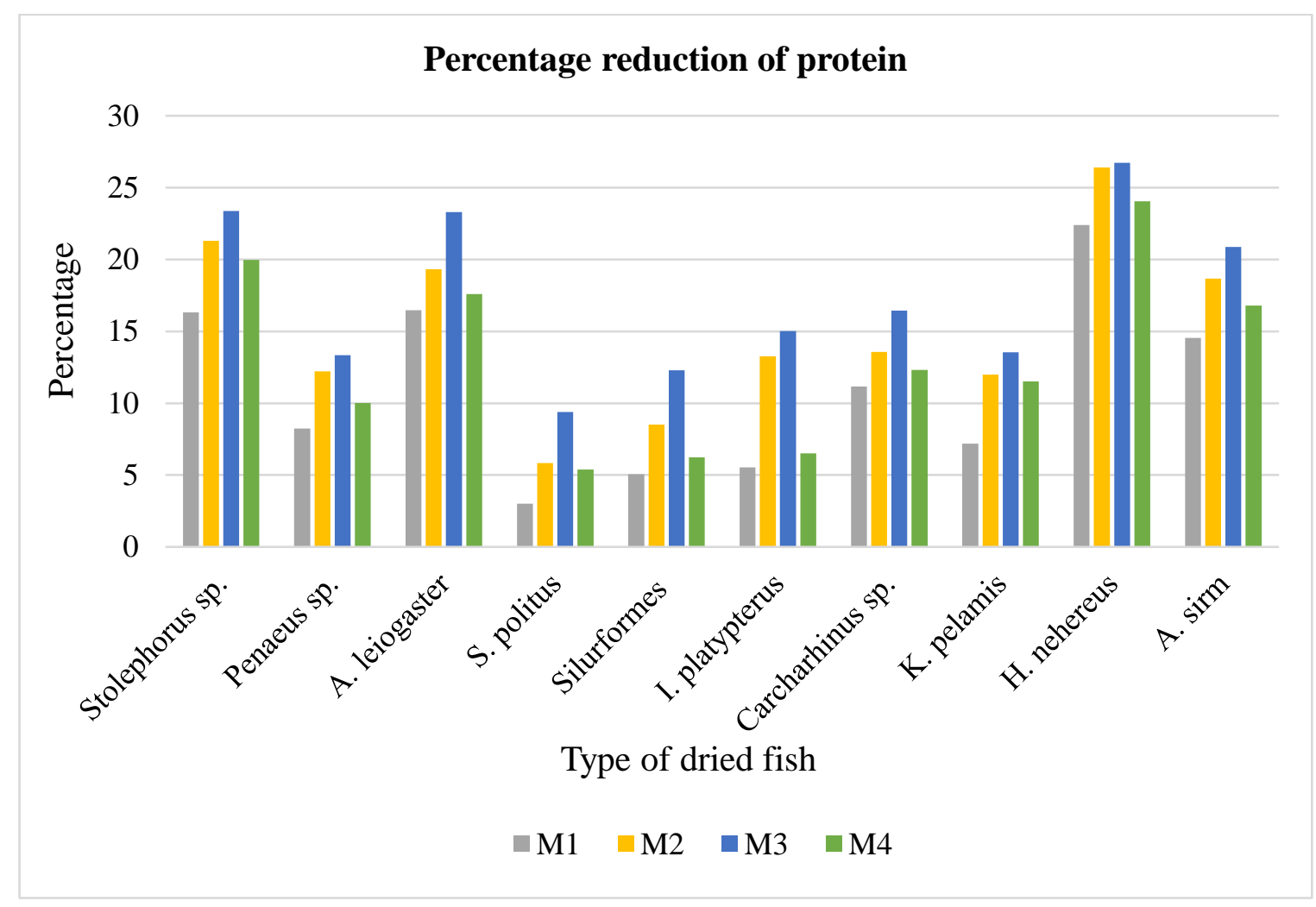

Figure 3. Percentage reduction of protein in each type of dried fish after applying salt reduction methods.

Based on the results, highlighted in Figure 2 and Figure 3, method 1 can be applied to reduce excessive amount of salt in dried fish except Penaeus sp (prawns) and Carcharhinus sp (Shark). It is the easiest way that can be used in households and this method reduces considerable amount of salt than the raw dried fish while leading to minimum protein loss. By applying method 4 also reduced the salt content in all analyzed dried fish samples significantly and the values were less than SLSI standard value of $12 \%$. This method is also more convenient, more economical and will not lead to high protein loss compared to methods 2 and 3. It is also easy to apply in households, since coconut water is a frequent waste in Sri Lanka. Hence method 1 and method 4 can be recommended to reduce salt content because they do not require energy as for methods 2 and 3. Even though Method 2 and 3 reduce high percentage of salt from raw dried fish, those methods are not recommended due to loss of freshness, high energy expenditure and fairly high protein loss.

*Correspondence: buddhika-gayani@mri.gov.lk

Tel: +94712088220

(C) University of Sri Jayewardenepura 


\subsection{Moisture content}

Moisture content of each type of dried fish is shown in Table 4. According to the results, the lowest moisture content of 13.66\% was recorded in Harpadon nehereus (Bombay duck) and the highest moisture content of $34.78 \%$ was recorded in Carcharhinus sp. (Shark). Differences in moisture content of dried fish could be due to variation in drying method, temperature, duration and texture. Drying time is also a considerable parameter in making dried fish and salted fish with higher initial value of water needs more time to dry as reported in Brás \& Costa, 2010.

Table 4: Moisture content (\%) of tested types of dried fish.

\begin{tabular}{llll}
\hline No. & Type of dried fish & & Moisture \% \\
\hline $\mathbf{1}$ & Stolephorus sp. & Sprats & $18.98 \pm 1.14$ \\
\hline $\mathbf{2}$ & Penaeus sp. & Prawns & $29.04 \pm 2.19$ \\
\hline $\mathbf{3}$ & Amblygaster leiogaster & Keeramin & $24.94 \pm 2.14$ \\
\hline $\mathbf{4}$ & Seriphus politus & Katta & $25.13 \pm 2.15$ \\
\hline $\mathbf{5}$ & Silurformes & Angulu & $26.27 \pm 1.64$ \\
\hline $\mathbf{6}$ & Istiophorus platypterus & Thalapath & $25.43 \pm 1.87$ \\
\hline $\mathbf{7}$ & Carcharhinus sp. & Mora & $34.78 \pm 1.62$ \\
\hline $\mathbf{8}$ & Katsuwonus pelamis & Bala & $27.35 \pm 1.76$ \\
\hline $\mathbf{9}$ & Harpadon nehereus & Bombili & $13.66 \pm 1.00$ \\
\hline $\mathbf{1 0}$ & Amblygaster sirm & Hurulla & $32.23 \pm 1.90$ \\
\hline & & & \\
\hline
\end{tabular}

Moisture content of dried prawns was found to be $29.04 \%$ in the present study while it was $24.2 \%$ in Sri Lankan sun dried variety of dried krill (crustacean) in a similar study conducted in Sri Lanka (Abeywickrama \& Attygalle, 2014). A previous study has recorded the percentage of moisture content for Talang queen dried fish collected from four different places ranged from $37.05 \%$ to $29.59 \%$.

In a similar study carried in India has shown the moisture content of six dried fish products collected from different markets of Assam, was in the range of $9.8 \%$ to $22.5 \%$ and all the values were lower than the BIS standards which declared a range of 10-35\% moisture for smaller fish and 40-45\% for some bigger fish (Ullah et al., 2016). It further says, the moisture content should be less than $25 \%$ in order to ensure a longer shelf life of dried fish while it should be below $20 \%$ for the quality dried fish with an expected shelf life of around 9-10 months (Kumar, 2013). In the current study only Stolephorus sp. (Dried sprats) and Harpadon nehereus (Bombay duck) had moisture content less than $20 \%$ implying only those two could have a shelf life of 9-10 months. A study carried out in Sri Lanka has shown that high moisture content above $60 \%$ leads to enhance colonization of fungi even at high salt concentrations (Atapattu \& Samarajeewa, 1990). 


\section{Conclusion}

The present study of salt content in dried fish available in CMC area in Sri Lanka, revealed that tested all types of dried fish except Amblygaster leiogaster (Smoothbelly sardinella), contain higher percentage of salt than the SLSI standard value of $12 \mathrm{~g} / 100 \mathrm{~g}$ on dry basis. Although method 2 and method 3 lead to fairly high salt reduction of dried fish, they are not recommended. Comparatively, method 1 and method 4 are more effective, more advantageous and easily applicable in households in salt reduction because these methods reduce considerable amount of salt to reach the SLSI standard, remove less amount of protein, do not require energy for boiling and retain freshness of dried fish.

This study reveals the possibility of reduction of salt of dried fish at the consumer level even if high salt is added by the producer. Thus it emphasizes the necessity of public awareness about high salt content in dried fish and health impacts of excessive salt consumption in order to reduce noncommunicable diseases. It further highlights the need of educating dried fish producers on the importance of adding minimal quantity of salt in processing while maintaining the proper drying and periodic inspection of dried fish making process by health authorities to regulate the salt and moisture content. Findings of this research will be helpful to prepare the Sri Lankan regulations to strengthen the Food Act under the ministry of health.

\section{References}

Abeywickrama, A., \& Attygalle, M. (2014). Comparative nutritional evaluation of three dried krill products commercially available in Sri Lanka. International Journal of Multidisciplinary Studies.

Analytical Methods Committee(AMC) (1979). Recommended general methods for the examination of fish and fish products. Analyst, 104(1238), 434-450.

Atapattu, R., \& Samarajeewa, U. (1990). Fungi associated with dried fish in Sri Lanka. Mycopathologia, 111(1), 55-59.

Beatty, S. A., \& Fougere, H. (1957). The processing of dried salted fish. Fisheries Research Board of Canada.

Brás, A., \& Costa, R. (2010). Influence of brine salting prior to pickle salting in the manufacturing of various salted-dried fish species. Journal of Food Engineering, 100(3), 490-495.

Ginigaddarage, P., I. Wickrama Surendra, W. Weththewa, K. Ariyawansa, G. Arachchi, K. Jinadasa, K. Hettiarachchi and R. Edirisinghe (2018). Microbial and chemical quality of selected dried fish varieties available in Sri Lankan market. Sri Lanka Journal of Aquatic Sciences, 23(1).

Ha, S. K. (2014). Dietary salt intake and hypertension. Electrolytes \& Blood Pressure: E \& BP, $12(1), 7$.

Kumar, K. B. (2013). Studies on the processing preservation and the nutritional value of Shidol a traditional fish product of Northeast India. Gauhati University, Retrieved from https://shodhganga.inflibnet.ac.in/bitstream/10603/50877/15/15_chapter\%207.pdf accessed on 10.08 .2020

Mansur, M. A., Rahman, S., Khan, M. N. A., Reza, M. S., \& Uga, S. (2013). Study on the quality and safety aspect of three sun-dried fish. African Journal of Agricultural Research, 8(41), 5149-5155.

Needham, S., \& Funge-Smith, S. J. (2015). The consumption of fish and fish products in the Asia-Pacific region based on household surveys (Food and Agriculture Organization of the United Nations, Regional Office for Asia and the Pacific, Bangkok, Thailand). RAP Publication, 12

*Correspondence: buddhika-gayani@mri.gov.lk

Tel: +94712088220

(C) University of Sri Jayewardenepura 
Nuwanthi, S. G. L. I., Madage, S. S. K., Hewajulige, I. G. N., \& Wijesekera, R. G. S. (2016). Comparative study on organoleptic, microbiological and chemical qualities of dried fish, Goldstripe Sardinella (Sardinella gibbosa) with low salt levels and spices. Procedia food science, 6, 356-361.

Official, A. O. A. C. (2000). Methods of analysis of AOAC International. AOAC International, Maryland, USA(2003)

Reksten, A. M., Somasundaram, T., Kjellevold, M., Nordhagen, A., Bøkevoll, A., Pincus, L. M., Aakre, I. (2020). Nutrient composition of 19 fish species from Sri Lanka and potential contribution to food and nutrition security. Journal of Food Composition and Analysis, 91, 103508.

Standards, S. L. (2007). Specification for dried fish, SLS 643:2007. Sri Lanka Standards Institution, Colombo, Sri Lanka.

Ullah, N., Hazarika, P., \& Handique, P. J. (2016). Biochemical Quality Assessment of Ten Selected Dried Fish Species of North East India. International Advanced Research Journal in Science, Engineering and Technology, 3(1), 30-33.

World Health Organization. (2012). Guideline: Sodium intake for adults and children. World Health Organization.

Yam, B. A. Z., Khomeiri, M., Amirkhani, S., \& Sabagh, M. (2015). Microbial quality of salted dried fish sold near Caspian Sea, Iran. Basic Research Journal of Microbiology, 2(4), 61-65. 